\title{
The productivity of the vetch and oat mix in crop rotation when using various fertilizer systems in the Vologda region
}

\author{
Olga Vasilievna Chukhina ${ }^{1, *}$, Larisa Alexandrovna Korelskaya ${ }^{2}$, and Nikolai Sergeevich \\ Demidov $^{1}$
}

${ }^{1}$ Federal State Budgetary Educational Institution of Higher Education "Vologda State Dairy Academy named after N.V. Vereshchagin" (Federal State Budgetary Educational Institution of Higher Education "Vologda State Dairy Academy"), Vologda Dairy, Russia

${ }^{2}$ North West Research Institute of Dairy and MeadowPaste Estate named after A.S. Emelianov is a separate unit of the Federal State Budget Institution of Science "Vologda Research Center of the Russian Academy of Sciences",) Vologda Dairy, Russia

\begin{abstract}
In 2017-2019, it was revealed that fertilizers provide $36-51 \%$ of the annual crops green mass yield, the collection of raw protein increases by $1.5-1.6$ times. When $\mathrm{N} 12$ was introduced against the background of phosphorus and potassium fertilizers, its content corresponded to $12.50 \%$, and when the $\mathrm{N} 75$ was introduced, it increased to $13.6-13.7 \%$. Takeaway for N, P, K increased with the use of $\mathrm{N}_{75} \mathrm{P}_{35} \mathrm{~K}_{130}$ 160 respectively by $1.5-1.6$ times, by 40 and $80-90 \%$ compared to control. The content of $\mathrm{NO}_{3}$ in green mass increased with the use of fertilizers, amounted to $72-86 \%$ of the maximum allowable concentration. The doses of $\mathrm{N}_{75} \mathrm{P}_{35} \mathrm{~K}_{130-160}$ fertilizers are $32-34$ ton/ha of green mass in a vetch and oat mix and the more negative balance of the fertilizer elements investigated.
\end{abstract}

\section{Introduction}

Dairy farming is developed in the Vologda region, so providing high-yielding cows with a balanced diet is one of the most important tasks of forage production.

To provide livestock farming with high protein feed on a large area in agricultural enterprises of North-West Russia cultivated perennial bean-grain herbs, in crop rotations mainly clover timothy mix. Annual crops such as pea and oat and vetch and oat mixes are of no small importance, which are distinguished by a high content of nutrients, including essential amino acids, are of great importance for the biologization of agriculture that are necessary in the structure of sown areas.

Fertilizers are given great importance when cultivating a vetch and oat mix. Scientific doses of fertilizer improve the quality and quantity of agricultural products, the accumulation of nitrates at the same time does not exceed the maximum allowable value [1, $2,3]$.

\footnotetext{
*Corresponding author: ochukhina@mail.ru
} 
Investigations were conducted to inspect the effect of minimal and calculated doses of fertilizer on the productivity of the green mass of the vetch and oat mix under the conditions of the European North of Russia in the Vologda region.

\section{Materials and methods}

The site of the field stationary experiment, located on the experimental field of the Federal State Budgetary Educational Institution of Higher Education "Vologda State Dairy Academy", during 2017 - 2019, in 4 several-fold repetition. Experimental plots are broken rectangular form with a total area of $140 \mathrm{~m}^{2}$, with the accounting area - more than $25 \mathrm{~m}^{2}$, with a systematic location. The soil of the experimental site has the following characteristics: sod-podsolic; according to the granulometric composition - medium clayloam; complies with the average level of cultivation. Experimental plots were located in a four-year field crop rotation $[3,4,5]$. The experience examined the varieties of vetch and oat, made in the State Register of breeding achievements, admitted for use in the North West zone of the Russian Federation [3, 4].

The experiment explored options: control (no fertilizer) (1 var.), $\mathrm{N}_{12} \mathrm{P}_{16} \mathrm{~K}_{16}$ (2 option), $\mathrm{N}_{75} \mathrm{P}_{35} \mathrm{~K}_{130}$ (3 option), $\mathrm{N}_{75} \mathrm{P}_{35} \mathrm{~K}_{160}$ (4 option), $\mathrm{N}_{50} \mathrm{P}_{20} \mathrm{~K}_{100}+$ afteraction 40 ton/ha of the decomposed dung (5 option).

At 3rd, 4th, 5th options of fertilizer doses for application were determined by the planned recommended balance ratios $(\mathrm{Kb})$ according to Yu.P. Zhukov. It was planned as the ratio of fertilizer elements removal by the planned yield of culture in 25 ton/ha to the dose of fertilizers applied in the converted percentages [6]. The actual $\mathrm{Kb}$ shows the balance of the fertilizer elements in the soil and was as the ratio of the actual removal of the fertilizer elements to the dose of their input.

During the experiment, fertilizers containing the main elements of N, P, K were applied according to conventional cultivation technology, in the main fertilizer $\mathrm{P}$ and $\mathrm{K}$, and $\mathrm{NH}_{4} \mathrm{NO}_{3}$ - under pre-planting cultivation, when sowing $\mathrm{N}_{12} \mathrm{P}_{16} \mathrm{~K}_{16}[3,4,5,7,8]$.

A solid method was used to account for the output of products from the unit area, then the green mass of crops led to humidity of $75 \%$, complying with the standard, to establish the ratio between crops (vetch and oat) sampled bundles.

To determine the content of element $\mathrm{N}$ in a green mass of cultures the method of Kjeldahl was used, raw protein - GOST 13496.4-93 (conversion factor 6.25), movable phosphorus - on a photocolorimeter, exchanged potassium - on a fiery photometer.

Dispersion analysis - in Excel with counting automation [9].

As the previous investigations of the authors on this issue have shown: complete calculation systems of fertilizers provide $53 \%$ of the green mass yield of annual forage crops, significantly - by $11-14 \mathrm{GJ} / \mathrm{ha}$ [7] and more (by 26.3-31.8 GJ/ha) [8] increase the collection of exchange energy by the green mass of the vetch and oat mix. The fact that fertilizers increase the yield and nutritional value of annual crops has also been established as a result of other investigations [10 - 13].

During the growing season of the vetch and oat mix, the hydrothermal ratio (HTR) in June 2018 was below the multi-year value. The high HTR was observed in 2017, exceeding the multi-year values in June and July more than twice. And 2019 was characterized by a lower temperature regime and excess moisture, especially in July (Figure 1). 


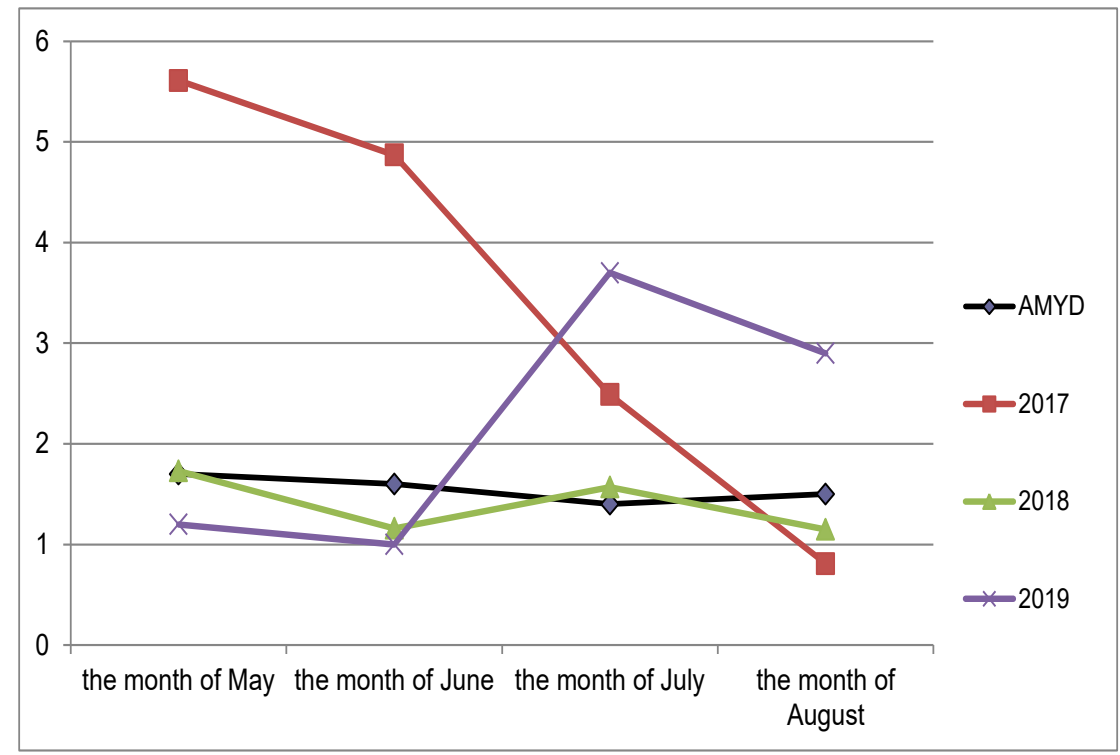

Fig. 1. The HTR by months of 2017-2019 investigations in comparison with AMYD (average multiyear data).

\section{Results and discussion}

In 2017-2019, when the productivity of annual forage crops was investigated, conditions were good for the growth and development of vetch and oat plants under the mix conditions, therefore, the planned level of crop productivity was achieved and even exceeded (Figure 2).

The most favorable conditions turned out to be in 2017, when excess moisture, optimal air temperature served favorably and ensured crop productivity, which, when $\mathrm{N}_{75} \mathrm{P}_{35} \mathrm{~K}_{130-160}$ was applied, exceeded both the other two investigated years and the average value by 4.1 3.0 ton/ha.

Doses of $\mathrm{N}_{75} \mathrm{P}_{35} \mathrm{~K}_{130-160}$ provided a significant increase in yield compared not only with the control (1 option), but also with fertilization only when sowing at a dose of $\mathrm{N}_{12} \mathrm{P}_{16} \mathrm{~K}_{16}$ (2 option).

During the investigation years, the inspected calculated doses of fertilizers differed insignificantly. Apparently, an increase in the dose of potash fertilizers from 130 to $160 \mathrm{~kg}$ of d.a./ha did not affect the index.

The investigated doses increased the yield of green mass up to 25.734 .1 ton/ha, as shown in other references $[3,4,5,7,8]$. 


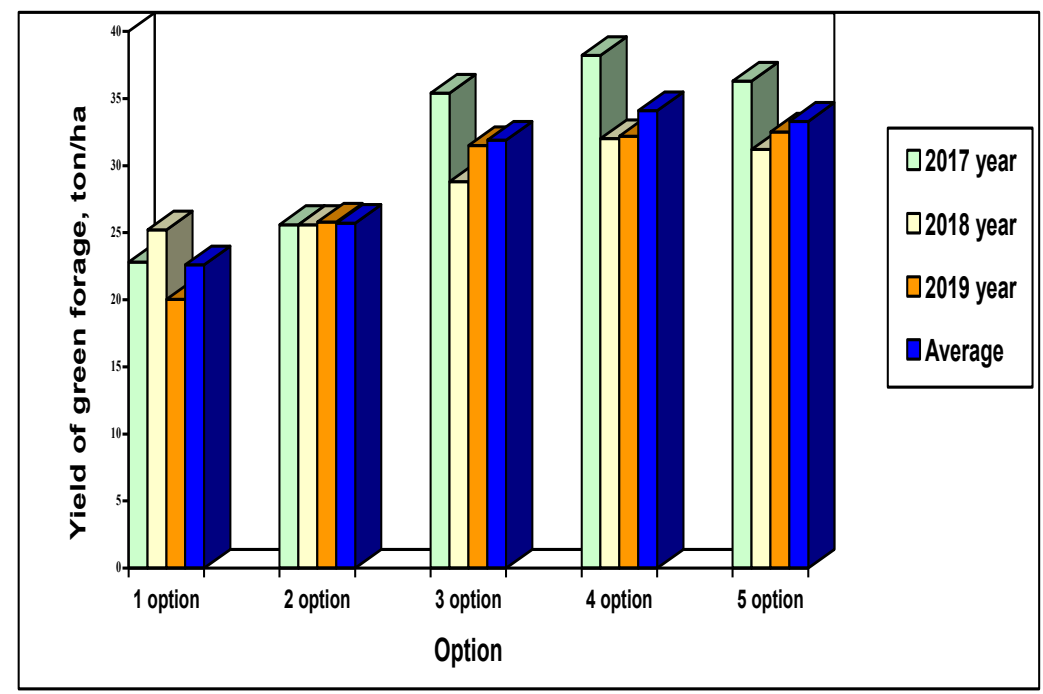

Fig. 2. Productivity of green mass obtained as a result of investigations for 2017-2019, ton/ha.

So, the productivity of cropped fallow (predecessors of winter rye) was $\mathrm{N}_{75} \mathrm{P}_{35} \mathrm{~K}_{130-160}$ 31.9 - 34.1 ton/ha when used.

The content of "raw" protein changed slightly depending on the weather during the investigation years. Its lowest value was observed in 2018, and the highest was in 2019 . Spring vetch, as a legume crop, used part of the nitrogen due to nitrogen fixation from the atmosphere. This amount accounts for up to $40 \%$ of the total nitrogen removal by the crop. Nitrogen nutrition and crops - a component of this mix, oats is improved. It is believed that it is required to significantly reduce the dose of nitrogen fertilization for this crop. And when applying N75, inhibition of the culture can be observed at the first stages of growth and development, although under our conditions the negative impact of high doses of nitrogen fertilizers was not observed on the development of crops in the mix $[4,5,6,7,11]$ (Figure 3). 


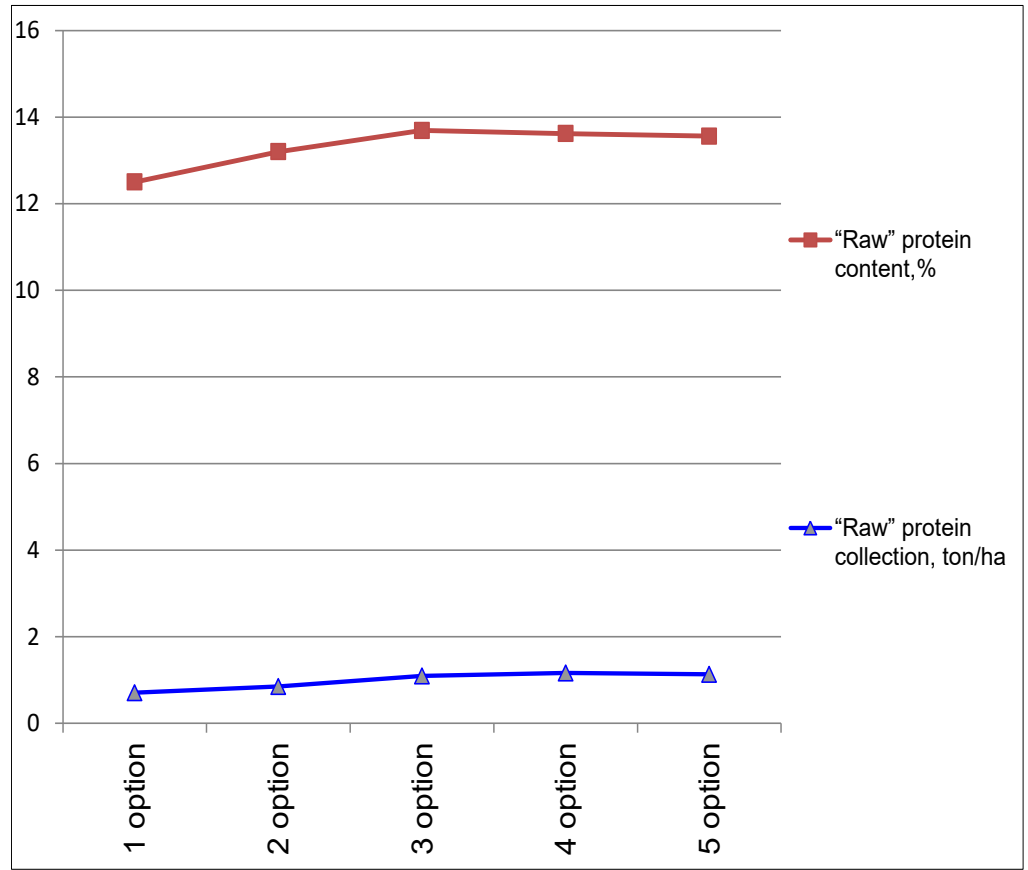

Fig. 3. Content in percentage and collection of "raw" protein, ton/ha.

The manuscript notes that with an increase in the doses of fertilizers applied, there is a tendency to an increase in the content of "raw" protein. So, when applying N12, its content complied with $12.50 \%$, and when applying N75, it increased to 13.56-13.69\%. Moreover, different fertilization systems, mineral and organomineral (options 3 and 5) differed only by $0.13 \%$ in absolute value and by almost $1 \%$ in the relative value of the trait. Apparently, increasing doses of nitrogen fertilizers are more important for growth and increase in protein content.

Protein collection changed significantly during fertilization compared with the control option, increased by 1.2 times in option 2 and 1.5-1.6 times when using the calculated doses (Figure 3), as in previous investigations [4, 9, 10]. Obviously, as the yield increases, the collection of "raw" protein also increases.

So, when applying N12, the content of "raw" protein complied with $12.50 \%$, and when applying N75, it increased to $13.56-13.69 \%$.

The content of $\mathrm{NO}_{3}$ increased in the green mass of the annual crops mix when fertilizers were used: the application of $\mathrm{N}_{12} \mathrm{P}_{16} \mathrm{~K}_{16}$ during sowing increased by $30 \%$; full doses of fertilizers (3-5 options) increased the content by $23-47 \%$. The application of $\mathrm{N}_{50} \mathrm{P}_{20} \mathrm{~K}_{100}$ against the background of the afteraction 40 ton/ha of organic fertilizers caused an increase in nitrates in comparison with the equivalent investigated mineral fertilization system by 14 $\mathrm{mg} / \mathrm{kg}$. The content of nitrates at doses of fertilizers $\mathrm{N}_{75} \mathrm{P}_{35} \mathrm{~K}_{130-160}$ amounted to $72-86$ percent of the maximum allowable concentration (MAC). In the experiment, with the application of nitrogen, phosphorus and potash fertilizers in the optimal ratio of elements for the culture, the content of nitrates exceeding the MAC is not observed (Figure 4).

So, the content of $\mathrm{NO}_{3}$ in the green mass of the annual crops mix increased by $30-47 \%$ when fertilizers were applied. 


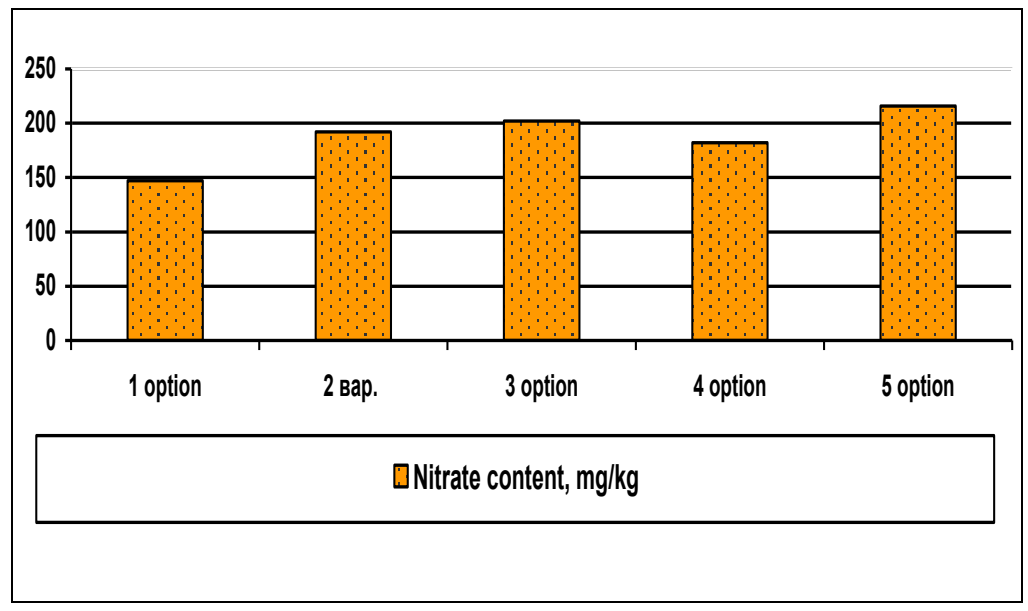

Fig. 4. $\mathrm{NO}_{3}$ content in vetch and oat mix for $2017-2019, \mathrm{mg} / \mathrm{kg}$.

The economic removal of nitrogen, phosphorus and potassium by the crop increased with the use of fertilizers. Nitrogen removal when applying $\mathrm{N}_{75} \mathrm{P}_{35} \mathrm{~K}_{130-160}$ exceeded control by $40-43 \mathrm{~kg}$. Moreover, the organomineral fertilization system of the crop (option 5) did not actually differ from the mineral fertilization systems, compare 118 and $119 \mathrm{~kg}$. The removal of phosphorus with the yield did not differ, it was $65 \mathrm{~kg}$ against the background of fertilizers. In terms of potassium removal, the organomineral and equivalent mineral systems did not differ; they were slightly inferior to the variant with the maximum dose of potassium, only by $12-13 \mathrm{~kg}$. Apparently, potassium is the limiting element in the soil under such conditions (Figure 5).

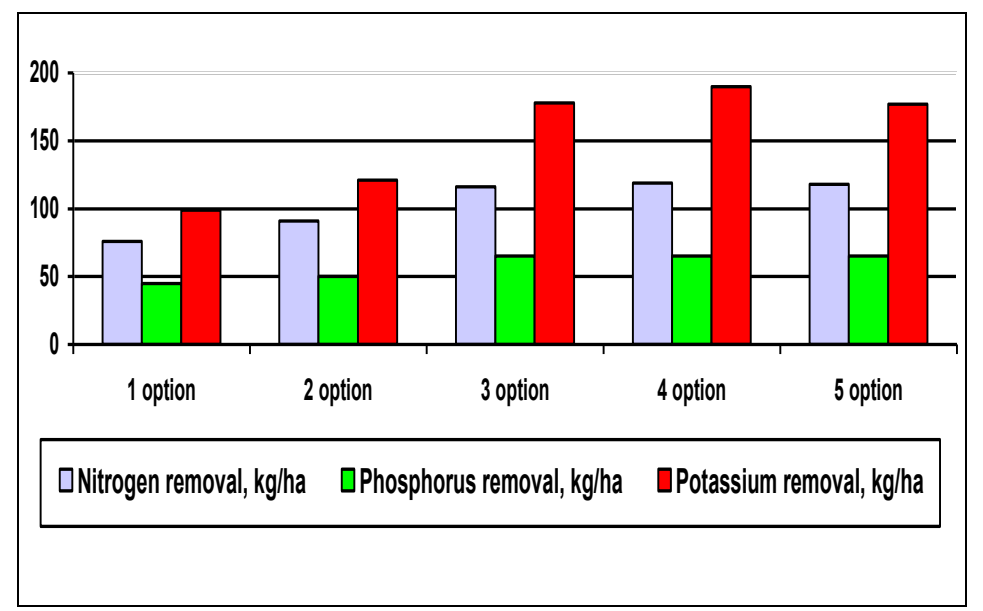

Fig. 5. Fertilizer elements removal in the experiment, on average for $2017-2019, \mathrm{~kg} / \mathrm{ha}$.

Fertilizer doses in 3-5 variants increased $\mathrm{N}$ removal by $50-60 \%, \mathrm{P}_{2} \mathrm{O}_{5}-$ by $40 \%$, and $\mathrm{K}_{2} \mathrm{O}$ - by $80-90 \%$ compared to the control.

It should be assumed that the actual balance factors of fertilizer elements will also increase in numerical terms with an increase in the element removal, while the balance will decrease.

Actual balance factors for nitrogen amounted to $155-158 \%$, exceeding the planned level by $35-38 \%$ in absolute value. They were significantly higher in phosphorus, by $85 \%$, in potassium, they exceeded the planned value by $36-39 \%$ (Figure 6). 
This is due to the fact that the removal significantly exceeded the planned value due to the high crop yield, which exceeded the planned level by $40 \%$.

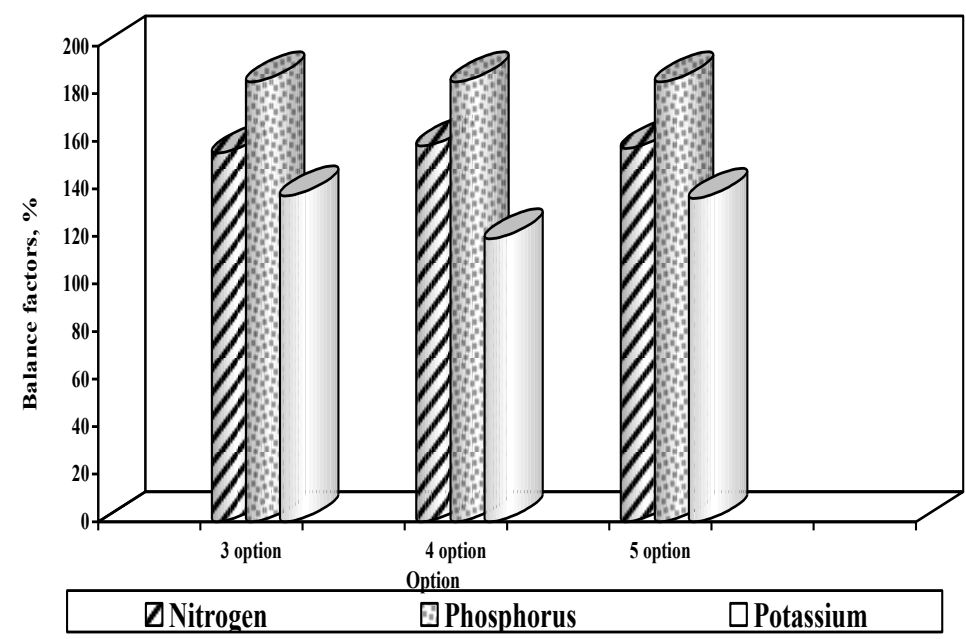

Fig. 6. Balance factors of fertilizer elements used obtained on investigation results, for 2017-2019, \%.

So, the actual balance factors for nitrogen amounted to $155-158 \%$, exceeding the planned level by $35-38 \%$ in absolute value, for phosphorus they were significantly higher than the planned ones, by $85 \%$, for potassium they exceeded the planned value by $36-39 \%$.

Consequently, the applied doses of fertilizer $\mathrm{N}_{75} \mathrm{P}_{35} \mathrm{~K}_{130-160}$ fertilizers when obtaining 34 ton/ha of green mass in a vetch and oat mix do not provide zero balance on fertilizer elements. A negative balance of all the fertilizer elements is detected, i.e. elements removal is much higher than the input with fertilizers.

Thus, the application of fertilizers at the rate of $\mathrm{N}_{75} \mathrm{P}_{35} \mathrm{~K}_{130-160}$ increases the yield of green mass by $36-51 \%$, the collection of raw protein - by 1.5-1.6 times compared to the control. Accordingly, the yield of plant residues after annual forage crops increases, which contributes to a greater return and accumulation of organic matter in the soil in comparison with other inspected options.

\section{References}

1. B. A. Yagodin, Agrochemistry, 584 (2016)

2. V. A. Pilipchak, Feed production, 5, 15-17 (2004)

3. O.V. Chukhina, Fertility, 1(106), 22-25 (2019)

4. O. V. Chukhina, Dairy Bulletin, 4(36), 141-154 (2019)

5. E. I. Kulikova, The influence of different doses of fertilizers on crop productivity and fertility of sod-podsolic soil in crop rotation: dissertation, 162 (2012)

6. Yu. P Zhukov, Land husbandry, 1, 40-42 (1988)

7. O.V. Chukhina, Nutritional value of vetch and oat mix when using fertilizers in crop rotation, 201-206 (2019)

8. O. Chukhina, IOP Conference Series: Earth and Environmental Science, 6th Int. Conf. on Agriproducts Processing and Farming, 012035 (2020)

9. B. A. Dospekhov, Field experiment technique, 351 (1985) 
10. O. P. Kamneva, On the complex use of lime and mineral fertilizers in the cultivation of vetch and oat mix for green fodder, 1(45), $116-121$ (2016)

11. T. P. Sabirova, Vladimirsky Agricolist, 4(86), 33-37 (2018)

12. A. N. Fadeeva, Feed production, 2, 14-16 (2001)

13. P. Hubert, S. Hugo, W. des Korner, Legume construction in Deutschland, RAPS, 12(1), 44-46 (1994) 